\title{
O MEIO AMBIENTE DOS CIGANOS DE APARECIDA DE GOIÂNIA (GO)
}

\author{
(The environment of Gypsies of Aparecida de Goiânia-GO)
}

\author{
Elza Kioko Nakayama Nenoki do Couto 12 \\ (Universidade Federal de Goiás - UFG)
}

\begin{abstract}
The purpose of this paper is to report and comment on a field work I have been conducting among the Kalderash Gypsies of Aparecida de Goiânia (GO) since 2009, emphasizing their natural and social environment from an ecolinguistic perspective. This group comprises roughly 250 people, converted to Evangelic religion. They are semi-nomadic and bilingual in Portuguese and Romanès, the local dialect of Romani, the general language of Gypies worldwide. The spatial distribution of the families in a single neighborhood facilitates a strong interaction among themselves. This includes visits, taking part in festivities, church going and so on. My thesis is that this spatial convivial favors the survival of their ancestral language and their ways of life. It is this sharing of the same natural environment that leads to at least a partial maintenance of the mental and social environment because they are interdependent. Keywords: social and physical environment, Ecolinguistics, Kalderash Gypsy.
\end{abstract}

\section{RESUMO}

O objetivo desta comunicação é expor e comentrar os resultados de uma pesquisa de campo que iniciei em 2009, e que continuo até hoje, com os ciganos Kalderash de Aparecida de Goiânia (GO), destacando o ambiente não só físico, mas também o social, vistos pela perspectiva

12. Doutorado e Mestrado em Linguística na PUC-SP. Professora de Linguística da UFG. Fundadora do NELIM - Núcleo de Estudos de Ecolinguística e Imaginário, na UFG onde atua como docente na Graduação e na Pós-Graduação. 
da ecolinguística. Trata-se de um grupo seminômade, composto por mais ou menos 250 integrantes. Atualmente eles se converteram à religião evangélica. Eles são bilíngues em português e romanês, dialeto do romani, língua universal dos ciganos. A distribuição tópica das famílias em um único bairro facilita a interação. Aí se incluem visitas, frequência a festividades, à igreja etc. A tese que defendo é a de que é essa proximidade espacial que permite a manutenção da língua e dos usos e costumes ancestrais. É a convivência no meio ambiente natural que garante a sobrevivência pelo menos em parte do mental e do social, uma vez que são interdependentes.

Palavras-chave: meio ambiente físico e social, Ecolinguística, ciganos kalderash.

\section{Introdução}

O presente artigo, situado no âmbito da ecolinguística, tem por objetivo expor parte de minha pesquisa com os ciganos Kalderash de Aparecida de Goiânia, iniciada em 2009 e que ainda se encontra em andamento, destacando a relação deles com o ambiente não só físico, mas também o social. O meio ambiente aqui é visto sob a perspectiva da ecolinguística, ou seja, na relação povo, língua e mundo natural, mental e social. Embora tenhamos na ecolinguística esses três meios ambientes e eles se encontrem inter-relacionados, neste artigo estudaremos apenas o natural e o social. O meio ambiente natural compreende o lugar físico e tudo que dele faz parte, inclusive os membros da população como corpos físicos. Na relação línguamundo social, verificarei como se dá a interação social dos ciganos Kalderash de Aparecida de Goiânia, seus costumes, sua língua, ou seja, como se dá a interação social via linguagem. O trabalho tem a seguinte organização: Na seção 1, apresento um breve relato sobre a história dos ciganos; na seção 2, temos uma explanação sobre o que vem a ser a Ecolinguística. Na seção 3, falo sobre o meio ambiente físico e social dos ciganos de Aparecida de Goiânia. Por fim, temos as considerações finais. 


\section{Breve relato sobre a história dos ciganos}

No início do século XIII, de acordo com China (1936, p.09), os primeiros ciganos que surgiram na Europa, diziam que eram originários do "Pequeno Egito", diziam que andavam errantes por penitência e declaravam que tinham vindo do Egito, mas quando se perguntava a eles sobre o assunto, não conseguiam informar onde ficava essa região. Para muitos ciganólogos, os ciganos são originários da Índia e não do Pequeno Egito, expressão que designava a Síria, a Grécia e Chipre. China (1936) argumenta que, se os ciganos tivessem como origem o Egito, haveria algum indício do copta ou do árabe em sua língua, pois, na primeira metade do século VII, os árabes conquistaram o Egito, cujo idioma era o copta.

Mota (1986) assevera que "Pequeno Egito" era então a denominação de uma região da Grécia, mas que pelos europeus foi confundida com o Egito, na África. Nesta perspectiva, os ciganos passaram a ser chamados "egípcios", ou gypsy (inglês), egyptier (holandês), gitan (francês), gitano (espanhol) etc. Alguns grupos diziam que eram gregos e atsinganos, e assim ficaram conhecidos como grecianos (Espanha), tsiganes (francês), ciganos (português), zingaro (italiano), etc. Moonen (1997) acredita que os ciganos não são originários da Índia, mas aí ficaram o tempo suficiente para assimilar alguns costumes e aspectos da língua local. Hoje, a maioria dos especialistas como Mota (1986), Hancock(1995), Couto (2002) acredita que os ciganos sejam originários da Índia e que, ao deixarem esse país, entre os séculos X e XI, devido aos sucessivos conflitos armados com as tropas islâmicas, dividiram-se em: rom, sinti, e calon.

Os rom falam a língua romani e são divididos em vários sub-grupos como os kalderash, matchuaia, lovara, curara. São predominantes nos países balcânicos, mas depois do século XIX migraram também para outros países europeus e para as Américas. Os sinti falam a língua sinto e se concentram mais na Alemanha, na Itália e na França, onde são denominados manouch. Os calon que falam o caló são chamados de "ciganos ibéricos". Eles vivem principalmente em Portugal e na Espanha, aqui conhecidos como gitanos. Esses ciganos se espalharam 
também para outros países da Europa e foram deportados ou migraram para a América do Sul. Apesar de constituírem diferentes grupos com diferentes línguas, atribui-se aos ciganos uma língua comum, o romani, que, durante 700 ou 800 anos, na Europa, fragmentou-se em cerca de 60 dialetos, que podem ser agrupados em dois: vlax e não-vlax, designação referente ao principado de Valáquia. O dialeto não-vlax era falado pelos calon e sinti dispersos pelo continente europeu, e o dialeto vlax, pelos ciganos que viveram como escravos na Romênia, em torno de 500 ou 600 anos. Devido ao contato que tiveram com outros povos e à sua adaptabilidade, o romani sofreu influência de outras línguas.

Mota (1986) afirma que, em vários países da Europa, os ciganos sofreram discriminações. Na Alemanha, no século XV, eram considerados os responsáveis pelas epidemias e calamidades. $\mathrm{Na}$ França, foram expulsos sob a acusação de serem feiticeiros e bruxos. $\mathrm{Na}$ Dinamarca, os chefes e grupos de ciganos eram mortos ou expulsos. A Inglaterra, no século XVI, negava aos ciganos o direito de asilo em igrejas e santuários, o que nenhum país cristão recusava, nem mesmo aos delinquentes. Com o fim da escravidão na Romênia, em 1855, os ciganos constituíram-se novamente em grupos, sedentarizando-se em diversas cidades ou migrando para regiões da Europa e para as Américas. A Europa os considerava improdutivos e perturbadores da ordem social, extraditando-os para as colônias da América e da África. Os primeiros ciganos que chegaram ao Brasil eram degredados de Portugal. Para Melo (2005: 42), os calons não são procedentes da Romênia, mas da Península Ibérica, têm dialeto próprio não vlax, que, muitas vezes, não é compreendido pelos demais grupos ciganos. Os rom, vindos da Europa Central e da Península Balcânica, chegaram ao Brasil após a emancipação política.

Segundo Mota (1986: 32), os kalderash, ferreiros que se consideravam nobres, vieram dos Balcãs e da Europa Central, preservando sua cultura e identidade. Os matchwaia, provenientes da Espanha, propensos à sedentarização, perderam sua identidade étnica; os rudari, provenientes da Romênia, vivem principalmente em São Paulo e Rio de Janeiro, tendo bom nível econômico; os horahané, provenientes da Turquia e da Grécia, são vendedores ambulantes; 
os lovara desprezam a sua cultura de origem, fazendo-se passar por imigrantes italianos; os calon, procedentes da Península Ibérica, têm dialeto próprio e são comerciantes e mecânicos.

No Brasil, há todas essas etnias de ciganos, mas em minha pesquisa estudo os Kalderash de Aparecida de Goiânia. Em 2009, conversando com Adriana Sadoyama, que se dedica aos estudos sobre os ciganos Kalderash em Uberlândia, surgiu a ideia de fazer a pesquisa com os Kalderash de Aparecida de Goiânia. Ela conversou com o líder dos kalderash de Uberlândia, Sr. Vidal, que se prontificou em me apresentar ao grupo de Aparecida de Goiânia, pois além de ele ter contato, ele tinha aí uns familiares também. Assim, ficou de vir pessoalmente para fazer a apresentação, mas uns dias antes do combinado ele telefonou-me e disse que havia tido um imprevisto, mas que já havia falado com o pessoal de Aparecida de Goiânia e que eu poderia encontrá-los tranquilamente. Afinal, já sabiam de minha pesquisa e estavam me esperando.

Em agosto de 2009, fui recebida pela família Castilho, meus informantes, nessa etapa: D. Isabel Castilho, apelido D. Margarida, 84 anos, matriarca da família; Alexsandro Castilho, apelido Mirlei, 48 anos, filho de D. Isabel e pastor da Igreja Evangélica da comunidade cigana; Olga Castilho, apelido Cristina, 61 anos, filha de D. Isabel; Márcia Castilho, 39 anos, esposa de Alexsandro; Rebeca, 12 anos e Mirely, 9 anos, filhas de Alexsandro e Márcia; Wanderlei, 41 anos, neto de D. Isabel, todos residentes no município há um ano.

Logo que cheguei, fui recebida pela matriarca Sra. Isabel Castilho (apelido D. Margarida), sua filha Olga Castilho, que prefere que a chamem pelo apelido Cristina, o neto da Sra. Isabel, Vanderlei, e a neta Rebeca. O filho, Mirlei que é o pastor da igreja Assembleia de Deus dos Ciganos, e a nora da Sra. Isabel, Márcia Castilho estavam viajando a negócios na "Cidade de Maranhão". Os apelidos, segundo os informantes, são escolhidos pela própria pessoa por não gostar do nome de batismo. Nesse primeiro encontro serviram o tchai (chá feito com canela, cravo, chá preto e pedaços de maçã, ameixa e banana), bolacha maizena e goiabada. Depois passaram um trecho do vídeo do casamento da neta da Sra. Isabel realizado em 
Uberlândia, a Sra. Isabel traduzia alguns trechos, pois o casamento é todo realizado em romanês. Interessante a fala do pai da noiva, em que dizia ao pai do noivo que a filha representava os dois olhos dele, ela é quem fazia os negócios dele e que, portanto, estava dando a eles os dois olhos dele e que esperava que eles a tratassem como filha e que ela deveria ser uma vendedora e não empregada da família. Desde esse primeiro encontro até hoje, faço pesquisa de campo com esses ciganos, gravando as entrevistas semi-estruturadas, tirando fotos, participando de suas festas como aniversários, almoços e cultos da igreja, assim neste artigo faço um recorte de minhas observações, destacando o meio ambiente natural e social dos ciganos Kalderash de Aparecida de Goiânia sob o viés da ecolinguística.

\section{Ecolinguística}

Para começar a falar sobre a ecolinguística, vale discorrer sobre o prefixo 'eco-'. Um dos significados de 'eco', segundo o dicionário Aurélio, é 'meio ambiente'. Além disso, EKOS é plurisignificativo, pois passa pelo grego oikos, casa, habitação, bens, família. Como curiosidade, temos em tupi-guarani ekó ' vida' e em latim echo, que corresponde a tudo que tem ressonância, reverbera, logo que será ouvido. O importante é que o prefixo 'eco-' nos lembra que a palavra 'ecolinguística' tem a ver com a ecologia biológica. Assim, se pensarmos no prefixo 'eco' como meio ambiente e tudo que está relacionado a esse meio ambiente, e linguística como sendo o estudo da linguagem, estudo de como os membros de uma comunidade comunicam entre si, tanto oral como gestualmente, temos a ecolinguistica, uma nova maneira de ver e estudar os fenômenos da linguagem, que, segundo Haugen (1972) é o estudo das interações entre língua e seu meio ambiente. Ora, o meio ambiente aqui é tudo que está no contexto da língua, tanto dentro quanto fora dela (o mundo, o território, o povo que a fala etc.).

Sabe-se que a relação entre língua e mundo já era estudada pelos gregos. No Crátilo, Platão, põe Hermógenes defendendo a tese 
de que a relação entre língua e mundo é natural, que a língua reflete o mundo, por exemplo, só existe a palavra 'árvore' porque existe a coisa árvore, não o contrário. Língua está ligada a mundo de modo natural. A palavra é um ser natural. O personagem Crátilo defende a tese de que a relação entre os dois é arbitrária, convencional. Língua está ligada a território pelo povo.

$\mathrm{O}$ assunto foi retomado ao longo de toda a história, tanto por filósofos quanto por linguistas. Em meados do século XX, o filósofo austríaco Ludwig Wittgenstein defendeu a tese de Hermógenes (a língua é um reflexo do mundo) no seu famoso Tractatus logicophilosophicus. Nota-se aqui que o importante é a língua como sistema para eu falar do mundo (sintaxe, morfologia, fonologia etc.). Pouco depois, Wittgenstein (1968) reviu essa posição e passou a defender a tese de que a língua é um jogo, isto é, ela existe basicamente para a interação entre as pessoas (para elas jogarem verbalmente, comunicarem-se). Para a ecolinguística a língua também é vista como interação, comunicação. Vários linguistas têm falado em "língua e meio ambiente" desde o início do século passado, tais como Edward Sapir (certamen te o primeiro), Einar Haugen (tido como pai da ecolinguística), o psicolinguista Kurt Salzinger e o linguista francês Claude Hagège, no livro L'homme de paroles (Paris: Fayard, 1985, p. 328). Nessa obra, ele disse que «uma futura ecolinguística deveria estudar o modo pelo qual são integradas na língua referências 'naturais' culturalizadas, tais como pontos cardeais, particularidades geográficas, habitações humanas, elementos cósmicos" (Hagège 1985: 328). Como uma população dá nomes às coisas de seu meio, de seu entorno. Vê-se que, para ele, a ecolinguística deveria estudar as relações entre língua e mundo natural.

Após vários ensaios menores sobre assuntos ecolinguísticos, no ano de 1993 surgiram dois livros de introdução à ecolinguística. O primeiro é de Alwin Fill: Ökologie: Eine Einführung. ([Ecolinguística: uma introdução]. Tübingen: Gunter Narr Verlag, 1993), infelizmente, disponível só em alemão. Há textos menores do autor em inglês na internet. Alwin Fill, da Universidade de Graz, Áustria, é considerado o guru atual da ecolinguística. O segundo é de Adam Makkai, cujo 
livro se intitula Ecolinguistics: ¿Toward a new ** paradigm*** for the science of language? (Londres: Pinter Publishers, 1993). Antes desse livro, Makkai já havia publicado textos menores, como "A pragmoecological view of linguistic structure and language universals" (Language sciences, 1972, p. 27.9-23). Adam Makkai, linguista da Universidade de Illinois at Urbana-Champaign, atualmente mora no Havai (aposentado).

No Brasil, quem primeiro falou em Ecolinguística foi o especialista em linguística aplicada Francisco Gomes de Matos, no texto em inglês "A case for ecolinguistic identity" (XXII. Internationale Deutschlehrertagung. Lucerna, Suíça, 30/7-4/8/2001) e em palestras e entrevistas em jornais. Nesse texto, Matos fala de língua como símbolo de identidade dos membros da população. A propósito da relação língua-identidade, o cigano europeu S. Dudrak disse o seguinte:

Diga-me, cara, onde estão nossa terra, nossas montanhas, nossos rios, nossos campos e nossos bosques? Onde está nosso país e onde estão nossas sepulturas? - Nós os temos nas palavras, as palavras de nossa língua (Courtiade, Marcel. 1985. "Aux origines des mots et des parlers rom”, Études tsiganes n. 1, p.16).

Nessa perspectiva, pode-se vislumbrar que a base de tudo na ecolinguística é o ecossistema fundamental da língua que consta de um povo $(\mathrm{P})$ residindo em determinado território $(\mathrm{T})$ e falando sua própria língua $(\mathrm{L})$. O povo que perde uma parte fundamental de sua identidade como o território ( $\mathrm{T}$ ) fica fragilizado. Só lhe resta a língua para expressar sua identidade. A médio e longo prazos pode ser aniquilado como grupo étnico específico.

Em 2007, surge o primeiro livro em português sobre a ecolinguistica, da autoria de Hildo Honório do Couto, linguista, professor associado da Universidaded de Brasília. Trata-se de Ecolinguística: estudo das relações entre língua e meio ambiente (Brasília: Thesaurus Editora, 2007, 462p.). Nesse livro, Couto diz que sob a perspectiva da ecolinguística tem-se o ecossistema fundamental da língua, que consta de língua $(\mathrm{L})$, povo $(\mathrm{P})$ e território $(\mathrm{T})$ que pode ser ilustrado da seguinte maneira: 


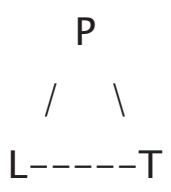

A linha tracejada entre $\mathrm{L}$ e $\mathrm{T}$ mostra que não há uma relação direta entre ambos, ela é sempre mediada por P. A totalidade formada por P, T e L passou a ser chamada de Ecologia Fundamental da língua (EFL), também conhecido como comunidade. Destacando a língua em seu interior, temos que o povo e o território constituem o seu meio ambiente (MA), ou seja, o MA fundamental da língua. O EFL pode ser representado como se vê na figura acima, em que $\mathrm{P}$ se equipara à população de organismos e T ao habitat, biótopo. Quanto a L, equivale às inter-relações que se dão entre os organismos da mesma espécie que formam a população. É por isso que a língua pode ser definida como sendo o modo de os membros da comunidade comunicarem entre si.

Vimos que para a ecolinguística tudo na língua tem a ver, direta ou indiretamente, com o Ecossistema Fundamental da Língua, melhor dizendo, com as relações entre L e P, por um lado, e entre L e T, por outro, bem como entre L e PT juntos, que são o MA Fundamental da Língua. Por exemplo, a distribuição dos indivíduos de $\mathrm{P}$ pelo espaço (T) determina muitas das características de L. Assim, se T é de pequenas proporções, como acontece com o $\mathrm{T}$ das pequenas comunidades ameríndias e africanas, L tende a ser relativamente homogênea. Se T abrange grandes extensões de terra, como o inglês, $\mathrm{L}$ tende a apresentar mais variação interna. Por fim, o nível intelectual e tecnológico a que os membros de $\mathrm{P}$ chegaram também pode afetar a natureza de L, sobretudo o vocabulário, mas não só, como, por exemplo, a morfologia, sobretudo na de formação de palavras, que tem a ver com ele, além de ser uma fonte de seu enriquecimento, permitindo criar novas palavras com meios internos, mediante a reutilização (reciclagem) de recursos já existentes.

Vale salientar que para a ecolinguística, o povo e a língua se relacionam com o respectivo meio ambiente, ou seja, o meio ambiente 
natural, o mental e o social. Na relação língua-mundo, o meio ambiente natural da língua é constituído pelo mundo, ou seja, os aspectos físicos do meio, aí inclusos os membros da população como corpos físicos. Se encararmos a língua como ela é formada, armazenada e processada no cérebro, melhor dizendo, nas conexões neurais nele existentes (as sinapses entre dendritos e axônios), constataremos que ela com essas conexões constituem meio ambiente mental da língua. Por fim, temos o meio ambiente social da língua, que é constituído pelos membros da comunidade organizados socialmente, vale dizer, a sociedade.

Quando falamos em meio ambiente natural, mental e social da língua não estamos dizendo que a língua é uma coisa que se encontra nesses meios (ambientes). Pelo fato de ela ser uma teia de interrelações ou interações, ao falarmos em meio ambiente fundamental, natural, mental ou social da língua estamos dizendo que é aí que se dão as inter-relações (interações) que a constituem. Podemos focalizar essas interações no meio/mundo natural (população seu entorno), no mundo/meio mental (cérebro/mente) ou no meio/mundo social (sociedade). Meio ambiente da língua é, portanto, onde se dão as interações, é o locus das interações.

\section{Meio ambiente físico e social dos ciganos de Aparecida de Goiânia}

O conceito de meio ambiente aparece na própria definição de ecolinguística que, desde a proposta original de Haugen (1972) é caracterizada como sendo o estudo das relações entre língua e meio ambiente. Nesse caso, duas perguntas se impõem desde o início:

(1) O que é meio ambiente?

(2) O que é o meio ambiente da língua?

A primeira pergunta nos remete à ecologia, em que o meio ambiente de uma espécie de seres vivos ou de um organismo isolado é o seu habitat, às vezes também chamado de biótopo, nicho ecológico ou território. Ao todo formado pela população de organismos e 
suas inter-relações com o meio ambiente, ou entorno, se dá o nome de 'ecossistema'. Vê-se, portanto, que meio ambiente é a parte do ecossistema em que se constatam essas inter-relações. Veremos que isso é de importância fundamental para os estudos ecolinguísticos, sobretudo a vertente que se pratica na Escola Ecolinguística de Brasília, a Linguística Ecossistêmica. Nesse contexto, uma definição mais apropriada de ecolinguística seria: estudo das inter-relações entre língua e seu contexto natural, mental e social. Outro modo de dizer a mesma coisa é: Ecolinguística é o estudo das inter-relações linguísticas que se dão no âmbito natural, no mental e no social.

Transpondo isso para os estudos linguísticos, estamos começando a dar uma resposta à segunda pergunta. Entendendo língua como uma teia de inter-relações (interações), como defendido por ecolinguistas como Adam Makkai, a conclusão inevitável é de que o meio ambiente da língua é o onde se dão essas inter-relações. No caso, verificamos que as interações da língua se dão entre os indivíduos da comunidade, equivalentes dos organismos da ecologia. Essa comunidade, que compreende um povo (P), seu território $(\mathrm{T})$ e seu modo de se comunicar, sua linguagem (L), constitui o ecossistema linguístico (comunidade linguística), que pode ser decomposto em comunidade de fala e comunidade de língua. A comunidade de fala (CF) é um ecossistema de pequenas dimensões, situado em um pequeno território, em que os atos de interação comunicativa se dão diuturnamente. Como acontece com o ecossistema ecológico, também o ecossistema linguístico é delimitado pelo observador. Para qualquer agrupamento de pessoas facilmente identificável e situado em determinado espaço, seu território pode ser assim delimitado. Veremos que o grupo de ciganos kalderash de Aparecida de Goiânia (GO) é um exemplo de CF, pois seus membros se constituem de famílias que residem no bairro Residencial Brasicon, de Aparecida de Goiânia e suas casas estão próximas umas da outras, mesma rua, em ruas paralelas e perpendiculares. A comunidade de língua (CL) já é bem mais fácil de ser caracterizada. Entendendo 'língua' aqui em consonância com a dicotomia de Saussure 'língua e fala', constatamos que CL se reporta ao sistema que se usa para 
interagir, para comunicar, melhor dizendo, é o como os membros da comunidade linguística se comunicam entre si verbalmente. A CL não pressupõe atos de interação comunicativa concretos, uma vez que é uma abstração, um conjunto de regras de comunicação. No caso, a CL dos ciganos compreende toda a comunidade de ciganos espalhados pelo mundo e cuja língua é chamada romani. Os kalderash de Aparecida de Goiânia usam uma variedade dessa língua conhecida como romanês.

\section{Os ciganos Kalderash de Aparecida de Goiânia e o meio ambiente natural e social}

Voltando ao conceito de MA da língua, verificamos que o lugar físico, a parte do bairro Residencial Brasicon em que os ciganos de Aparecida de Goiânia se encontram é o seu meio ambiente natural. Veremos que a sua disposição física tem implicações para a manutenção da língua original (romanês) e de parte das tradições culturais. Ao falar em tradições culturais e língua, estamos no domínio cultural, de natureza social. O social só existe porque está na mente dos indivíduos que constituem a sociedade. Assim, temos que reconhecer pelo menos mais dois meios ambientes da língua, o mental e o social. O meio ambiente mental da língua é constituído pela mente e pelas interconexões neurais que se dão no cérebro dos falantes, seria o como a língua é formada, armazenada e processada no cérebro (conexões neurais), levando em consideração a questão da adaptação. Aqui, não vamos tratar dele, uma vez que requer conhecimentos especializados. Só vou acrescentar ao já mencionado o meio ambiente social da língua, que é o conjunto de indivíduos da população, considerados em conjunto e organizados comunitariamente, ou seja, a sociedade. Assim, o meio ambiente social refere-se à sociedade, conjunto de pessoas que compartilham propósitos, gostos, preocupações e costumes, e que interagem entre si constituindo uma comunidade. 


\subsection{MA Natural}

A comunidade dessa pesquisa é formada por um grupo seminômade, de mais ou menos 250 integrantes, que residem no município de Aparecida de Goiânia-Goiás, no bairro Residencial Brasicon. Suas casas estão próximas umas da outras, na mesma rua, em ruas paralelas e em ruas perpendiculares. A maioria mora em casas, sendo que cinco famílias moram em tendas, por falta de condições financeiras. Os ciganos também kalderash de Uberlândia, estudados por Fonseca (1996), moravam em acampamentos, que são conjuntos de tendas, em geral em círculo, de modo que há um espaço coletivo no centro. Essa distribuição tem uma finalidade. Segundo a autora, "os espaços são organizados para restringir ao máximo o contato com os não ciganos e, ao contrário, propiciar uma intensa interação de seus membros" (FONSECA, 1996: II).

Os ciganos de Aparecida de Goiânia já perderam um pouco desse arranjo espacial devido ao fato de se localizarem em um bairro da cidade, com seu traçado de ruas já estabelecido pela administração municipal. Assim sendo, não dispõem de um espaço central comum, que os isole dos gadjé (não ciganos) como acontecia com os de Uberlândia, pelo menos no início da década de noventa, quando a pesquisa foi feita. Para a tradição cigana original:

essa forma do espaço permite não só que o cigano veja sempre o horizonte, a fim de não se sentir 'preso', como também que todos tenham uma visão ampla do acampamento e, consequentemente, de todas as tendas, o que facilita o controle social do grupo sobre o indivíduo. Dentro desse círculo de solidariedade, não deve existir segredos domésticos" (Fonseca 1996: 72). Na sociedade tradicional, "os acampamentos em geral reúnem várias tendas ocupadas por famílias nucleares pertencentes a uma família extensa patrilinear. Então, a unidade espacial básica da sociedade cigana é a família extensa do homem, cujas famílias nucleares, no entanto, vivem em tendas separadas" (p. 73). Ainda segundo a autora, "o princípio da residência patrilocal é outro fator determinante na reprodução das relações sociais. Tem a função de permitir não somente a articulação política exercida pelos 
homens, como também um maior controle sobre as mulheres (FONSECA, 1996: 73).

No início da pesquisa a família cujos membros serviram de informantes para mim morava, de agosto de 2009 até outubro do mesmo ano, em um terreno grande medindo aproximadamente $10 \mathrm{x}$ $40 \mathrm{~m}^{2}$. Neste terreno havia uma tenda de lona que o cobria quase todo, havia um espaço grande na frente onde se colocavam cadeiras em dias de culto (domingo às 20 horas, pois se tornaram evangélicos), havia uma mesa grande ao lado a pia, armários, geladeira e fogão, depois um pouco distante havia tapetes e uma cama de solteiro onde dormia a matriarca. Os outros dormiam em colchões que colocavam sobre os tapetes na hora de dormir. Do lado dos colchões empilhados havia um computador e uma televisão. Não havia guarda-roupas, as roupas ficavam em malas e algumas penduradas em um varal improvisado. A água e a luz eram puxadas clandestinamente, ou seja, puxavam da casa vizinha e pagavam a essa vizinha certa quantia em dinheiro. Do lado de fora da tenda havia o banheiro, com pia e chuveiro e um tanque para lavar as roupas.

Em outubro de 2009, eles se mudaram para uma casa, que fica a cinco quadras de onde estava a tenda. Nos primeiros meses, após a mudança, a matriarca estranhava muito, e ficava muito triste. Um dos motivos é que a nova casa fica a cinco quadras do agrupamento principal de casas ciganas. Mas, a causa principal dessa tristeza é o fato de a casa de certa forma não permite a liberdade de locomoção, de contato com os outros ciganos, pois tem um portão de entrada no terreno, e uma porta com chave. A tenda, ao contrário, além de ficar em um lote com bastante espaço, ficava praticamente aberta, o que facilitava a visitação constante de outros ciganos que vinham com muito frequência para bater papo e comer. A palavra tenda em romani (e romanês) é tsera, associada ao romeno tsara, que significa terra, país. Como disse Fonseca (1996: 42) dos kalderash de Uberlândia, "a tenda pode então ser entendida como a terra cigana". Por outras palavras, para a matriarca, deixar a tenda era como deixar a "terra", a "pátria" ancestral. A autora acrescentou, ainda, que: 
para o cigano, que não tem pátria, ou melhor, que considera o mundo como a sua pátria, não poder participar da vida comunitária e até mesmo circular pelos seus espaços públicos e privados tem a conotação de estar exilado, obrigado mesmo a viver no espaço da e na sociedade gadjé, que ele sabe não ser o seu lugar (p. 62).

Nota-se que, a despeito de as residências não estarem dispostas na forma cigana ideal (acampamento com um espaço central comum), pelo menos estão relativamente próximas umas das outras. Essa distribuição tópica em um único bairro facilita a interação. Aí se incluem visitas, frequência a festividades, à igreja (evangélica) etc. Entre essas interações, salienta-se a interação comunicativa, ou as conversas, que se dão em romanês. Assim sendo, defendo a tese de que a proximidade espacial permite a manutenção da língua e dos usos e costumes ancestrais. É a convivência no meio ambiente natural que garante a sobrevivência pelo menos em parte do mental e do social, uma vez que são interdependentes, há um inter-relacionamento entre eles. Apesar de tudo isso, o grupo de ciganos kalderash de Aparecida de Goiânia constitui uma comunidade de fala, embora uma comunidade de fala difusa, não uma comunidade de fala compacta como a de Uberlândia. De qualquer forma, as duas são comunidades de fala complexas, pois em ambas duas línguas são usadas, o romanês e o português. Só temos comunidade de fala simples quando ela é monolíngue e monodialetal, como em algumas comunidades étnicas ameríndias.

\subsection{O MA Social}

Esse grupo cigano continua falando a língua original, romanês, embora sejam proficientes também em português, ou seja, são bilíngues. Atualmente, porém, a maioria deles se tornou evangélica, o que tem muitas implicações para os seus costumes, como veremos mais adiante. Pode-se considerar que esse grupo atualmente deixou de ser nômade e passou a ser seminômade. Afinal, 15 anos atrás seus membros viajavam de cidade em cidade, tinham um circo com cadeiras para mais de 200 pessoas. Nesse circo, apresentavam 
números circenses como, por exemplo, o da metamorfose: A Olga/ Cristina ficava de um lado e seu primo de outro, pelos jogos de luzes havia a ilusão de que havia a transformação da mulher para o homem gorila, passavam filmes em telões em vários estados, como na Bahia. Os filmes de rolos eram na maioria de faroeste e eram alugados de produtores de filmes de São Paulo e Belo Horizonte. Disseram que os filmes que mais faziam sucesso eram dos atores Tony Vieira, Claudette Joubert, Heitor Gaiotti-cara de gato, en com certa nostalgia disse uma informante que dois filmes desses atores faziam muito sucesso: A filha do padre e Violentadas. Nesses 15 anos, também trabalharam como vendedores ambulantes, sem se fixarem por mais de dois meses em uma cidade e morando em tendas. Já foram vendedores de panelas, tachos, jogos de bacias, toalha de banho, bolachas, maçãs, dizem que vendiam muitas maçãs, colocavam alto falante no carro e anunciavam a venda de maçãs. Atualmente, apesar de serem comerciantes de kits de colchas e panelas e chegarem a ficar em outras cidades até por dois meses, mantêm domicílio em Aparecida de Goiânia.

Quando viajam para outros estados, ou cidades distantes de Aparecida de Goiânia, os kalderash ficam em hotéis, ou alugam casas, tudo depende do tempo que ficarão. Dificilmente ficam em tendas de lona armadas, mas quando vai a família toda e estão sem condições de alugar uma casa, procuram a prefeitura da cidade para conseguirem um terreno e autorização para armarem as suas barracas. A prefeitura oferece a eletricidade, a água é difícil e daí tomam banho em postos de gasolina. Como as demais famílias, quando viajam, dificilmente levam todos os membros da família, a não ser que o planejem ficar mais de seis meses fora. Se viajarem o pai e a mãe ou o pai e os filhos que já estão na idade de comercializar (16 anos), os demais membros ficam em casa.

Ao cigano é difícil conseguir um imóvel para alugar, mesmo no bairro onde vive o grupo de 250 ciganos, muitos há mais de 10 anos. A discriminação ocorre em supermercados também, pois como relatou um dos informantes: "na semana passada eu fiz compra do mês e eles disseram que aceitavam cheques, na hora que eu estava preenchendo o cheque minha esposa chegou então o gerente percebendo que nós 
somos ciganos, disse que não poderia aceitar o cheque, fazer o quê, deixei as compras".

A família pesquisada e a maioria dos ciganos da comunidade são da Assembléia de Deus da Comunidade Cigana, pentecostais, assim, as orações, os louvores são seguidos de instrumentos como guitarra, teclado e em voz altíssima. Os louvores e a maioria dos testemunhos são realizados em romanês. Como muitas mulheres acima de 60 anos são analfabetas e muitos homens têm dificuldades de ler, o entendimento da bíblia é feito pelo pastor Alexsandro ou pelo Vanderlei, presbítero da igreja. Como a maioria é evangélica, as mulheres não mais leem as mãos, nem realizam as festas de promessas (Islava), que duravam de três a cinco dias, pois dizem não acreditarem mais em santos como os católicos. A festa de promessa é realizada para o santo de devoção caso consigam a graça pedida. Assim, por exemplo, se há alguém doente, fazem promessa normalmente a Nossa Senhora da Aparecida, ou a Santa Luzia, na qual se forem atendidos, fazem uma festa durante, por exemplo, três anos com comidas ciganas, assados, bebidas que são servidos aos ciganos convidados.

Os homens não usam chapéu e camisas bordadas e as mulheres usam saias ou vestidos longos, porém, não mais com de cinco metros, por razões financeiras e porque não querem ser identificados como ciganas, o que poderia prejudicar as vendas devido aos preconceitos. As mulheres casadas usam lenço na cabeça, como a matriarca, ou uma fitam, como faz a nora da matriarca. No tempo da matriarca, os pais é que escolhiam o noivo ou a noiva, que se conheciam apenas no dia do noivado. Neste dia, os pais do noivo dão à noiva a um colar, a queparka, uma corrente de ouro com moedas de ouro, símbolo do noivado. Este costume ainda se mantém.

Hoje em dia, diz a matriarca, não são os pais que escolhem o noivo ou a noiva, quando o homem se interessa por uma moça cigana, fala aos pais dela sobre o seu interesse, enfatizando que a moça pela qual tem interesse é honesta, bonita e trabalhadeira, daí comenta com os pais se eles gostam e combinam de pedir ao pai da noiva a permissão para o namoro. Caso haja aceitação, já combinam uma data para o casamento também. Antes do casamento há a festa de noivado, 
os noivos não trocam alianças, a mulher cigana ganha do pai do noivo um colar de moedas de ouro (queparka), que deve ser usado até o dia do casamento. Esse colar é o símbolo de que a mulher está noiva. Há uma superstição de que quanto menos a noiva tirar a queparka mais cedo o casamento se realizará.

A matriarca disse que nenhum deles começa a namorar sem que os pais tenham conversado anteriormente, e o pai do namorado vai falar com os pais da namorada, dizendo que queria a permissão deles para o namorado. A matriarca diz que quando estão namorando e mesmo noivos, nunca podem sair ou ficar sozinhos, sempre deverão estar acompanhados por um dos familiares como irmão, tio, mas que de vez em quando há umas escapadinhas para dar um beijinho. As despesas do casamento, festas, vestido da noiva são responsabilidades dos pais do noivo, inclusive há a questão do dote. Conforme a tradição do dote, o pai do noivo deve oferecer aos pais da noiva moedas de ouro, que antigamente eram cinco moedas de ouro, o chamado ustriako, libras esterlinas, e que atualmente são três moedas, dependendo da situação financeira dos pais do noivo. Essas moedas são feitas em ouros que a família possui ou compradas em São Paulo, Belo Horizonte. As moedas são dadas aos pais da noiva, e os pais da noiva, por conseguinte, oferecem uma moeda à filha, para que possam começar a vida de casal, é como um auxílio na parte financeira do casal. Tudo era dado pelo pai do noivo, nada era dado pelo pai da noiva.

Em relação às festas de casamento, a Sra. Isabel disse que, tempos atrás, as festas duravam cinco dias, na qual se convidavam todos os parentes que moravam distantes também. Armavam um circo onde era realizado o casamento, e em volta do circo os convidados levantavam suas tendas e ficavam ali durante os cinco dias do casamento. Atualmente, a festa dura três dias ou até dois; para as festas são alugados salões. No primeiro dia, a noiva se veste de branco, tem-se a cerimônia Nesse dia de festa há no salão duas bandeiras com os nomes dos noivos, simbolizando que ambos eram solteiros. Essas bandeiras ficam antes um tempo na casa dos noivos. Há muita dança e música, apenas as bebidas alcoólicas é que são proibidas devido 
à conversão, e isso, conforme a Sra. Isabel tem ocasionado alguns atritos durante a festa, pois alguns ciganos ainda não são convertidos.

No dia da festa do casamento há num tecido um coração bordado escrito, por exemplo: "casamento de Maria", "casamento de João". Bandeiras são colocadas nas barracas dos noivos e depois dançam com as bandeiras vermelhas. O significado das bandeiras é que eles eram solteiros. Podem ser bordados com corações e os nomes dos noivos. No caso de casamento de pessoas separadas, que já foram casadas, não usam nenhuma bandeira. Embora o dote seja menor, pois já foram casados, ainda se oferece o dote, para não dizer que deu a noiva de graça. Os casamentos são realizados entre ciganos, não sendo bem vistos os casamentos com gadjos, ou gadjes, não ciganos. Se isso acontece, o casal tem que seguir os costumes dos ciganos. A maioria dos casamentos é entre primos.

A virgindade da mulher é fundamental, por isso, os namoros são vigiados e os casais devem sempre estar acompanhados por um membro da família. A questão da virgindade ainda incomoda muito as mulheres ciganas, não em si, mas pela forma como é divulgada. Na festa de casamento, os noivos vão ao hotel, acompanhados dos padrinhos e madrinhas, que ficam do lado de fora do quarto, perto da porta. Após o ato sexual, entram no quarto e olham o lençol, que deve estar manchado de sangue, prova de que a noiva era virgem, e vasculham tudo, para ver se não houve alguma simulação ou trapaça. Tal desconfiança incomoda as mulheres ciganas, que afirmam que toda virgem sangra, pois deve ficar passiva, sem reclamar da dor. Constatada a virgindade, todos voltam à festa, levando champanhe e buzinando, e a alegria é geral. No dia seguinte, a festa de casamento prossegue, às vezes, na casa dos pais da noiva, ou no próprio salão alugado. A noiva, nesse segundo dia, usa um vestido vermelho, símbolo de que não é mais virgem. Fica na porta do salão com um jarro d'água com pétalas de flores e joga um pouco dessa água nas mãos dos convidados que devem dar um dinheiro à noiva, como nos casamentos de não ciganos na quais se cortava a gravata e os convidados davam dinheiro por um pedaço dela.

Se antes do casamento perde a virgindade, a mulher foge com o namorado, pois isso é uma vergonha para a família. Se for o filho 
mais novo, a esposa deve morar com a família dele, pois the cabe o sustento da mãe, do pai e das irmãs solteiras. Caso contrário, moram em suas casas, mas sempre próximos da família. As esposas devem servir em tudo ao marido: cortar as unhas, entregar a toalha de banho e as roupas, fazer as malas de viagem. Além disso, as mulheres ciganas é que trabalham mais nas vendas, pois elas têm mais facilidade de falar com outras mulheres ao mostrar as colchas e edredons. Os ciganos não convertidos, ou seja, os nãos evangélicos, ainda mantêm alguns costumes em relação aos mortos, aos quais muito temem, pois acreditam em assombração etc. Assim, os mortos são enterrados com pratos quebrados, para que se cortem e morram, se acordarem.

Durante três dias após a morte, não tomam banho nem lavam a louça com sabão, pois a espuma pode afogar o morto, tiram as pimentas e molhos de pimenta de casa após as 18 horas, para não arderem os olhos do morto. Esses costumes e outros, como festas de São João, as islavas e festa de promessas foram abandonadas apenas pelos ciganos evangélicos da comunidade de Aparecida de Goiânia. Dão grande importância à limpeza, lavando a louça, usam duas esponjas, uma para vasilhas com gordura e outra para copos. Não comem alimentos que foram tocados por outras pessoas, mesmo sendo da família, usam duas toalhas de banho, uma para enxugar a parte de cima do corpo e uma para enxugar a parte de baixo. Consideram a parte de baixo suja.

Os que têm mais de 60 anos são analfabetos, as crianças e os adolescentes vão à escola até a quinta ou sexta série do ensino fundamental, pois, pela tradição cigana, não precisam da escola, mas apenas saber ler e fazer contas, pois serão vendedores ambulantes, não empregados. Assim como afirma um dos informantes:

a gente não trabalhava pros outros, então a gente já sabe, a gente nasce e sabe que vai ser vendedor, estuda até certo tempo porque não vai ter um emprego fixo, então não precisa de segundo ou terceiro grau, para ele trabalhar para si próprio, nós ciganos sabemos disso e também já nascemos com o dom da venda. Também, vai aprendendo com os pais, olhando como os pais fazem. 
Quanto às vendas, se viajam a outros estados, sempre vão em grupos, nunca uma família só, só vai uma família quando se trata de uma cidade próxima a Aparecida de Goiânia. Costumam vender as colchas ou jogos de casa em casa, ou para lojas, fazem pedidos de kit de colchas a um comerciante cigano de Ibitinga. Ele entrega a mercadoria na cidade onde estão os ciganos que fizeram o pedido, por exemplo, se estão fora de Aparecida de Goiânia, em outros estados, saem de Aparecida com um número de kits de colchas, prevendo a chegada da compra de outros kits na cidade ou estado onde ficarão. Daí fazem a venda, se o comércio estiver bom, vão fazendo pedidos ao comerciante de Ibitinga e esperam as mercadorias para revenda.

Em relação ao uso do romanês, pude perceber durante todo esse tempo de pesquisa que se trata de um grupo que o usa mais que o português, quer falando diretamente ou pelo telefone. Usam a língua portuguesa quando falam com os nãos ciganos.

\section{Considerações finais}

É importante retomar alguns temas já mencionados acima. Mas, antes, gostaria de salientar que os ciganos são um povo desterritorializado (estavam territorializados no noroeste da Índia), que se reterritorializou na Europa do Leste. O problema é que devido a inúmeras perseguições, grande parte deles se deslocou daí também, emigrando para as quatro direções. Hoje em dia, há grupos tentando se re-reterritorializar em diversos lugares do mundo, como é o caso dos já mencionados ciganos kalderash de Uberlândia e de Aparecida de Goiânia, objeto do presente estudo. Diante de dessas vicissitudes, eles têm que manter suas tradições, entre elas a língua, a fim de manterem a própria identidade. Nesses comentários finais, gostaria de falar de mais algumas características de sua cultura que contribuem para essa identidade. Vejamos o papel da mulher. Na visão de Maria de Lourdes Fonseca (1996, p. 73), «o controle sobre as mulheres é especialmente importante para a preservação e sobrevivência do grupo, pois é ela que detém potencialmente o poder de poluição, através das relações sexuais, 
do parto e da preparação dos alimentos». A referida autora acrescenta que «o tabu de poluição é uma das formas de se manter diferente dos gadjé e também de expressar e reforçar um limite étnico" (p. 55-56) e que "certas áreas [do corpo] são designadas como santificadas e puras (a cabeça, a boca, a região superior inteira do corpo), ou impuras (parte baixa do corpo, especialmente as genitálias).

Os ciganos de modo geral evitam contato com os gadjé. Por exemplo, geralmente evitam comer juntamente com eles, embora $\mathrm{o}$ ato de comer seja um ato de socialização muito importante entre os próprios ciganos. Como os ciganos que estudo se tornaram evangélicos, deixaram de lado alguns traços de sua cultura original, como o ato de comer junto. Eles me admitiram em sua mesa em diversas oportunidades, com a prodigalidade de alimentos típica de sua cultura. Retomando a questão do espaço, uma vez que meu objetivo foi analisar o 'meio ambiente' do grupo de ciganos em questão, notase que o espaço pode compreender apenas um acampamento, uma caravana se deslocando, uma tenda etc. De certa forma, o território das comunidades de fala ciganas é móvel, portátil. Mesmo assim, ele é de fundamental importância para sua identidade. Fonseca (1996: 15) afirma que "a organização do espaço não [é] somente reprodução simbólica, mas também agente ativo”, uma vez que ela é determinante de padrões de encontros de uma área". No que tange às relações com os não ciganos, sabemos que não se pode enganar nem trapacear nas interações com um rom, nome eles próprios se dão. No entanto, enganar um gadjô não é tido como feio, uma vez que ele não é "limpo", mas marimé, ou seja, poluído. Pode até ser considerado um grande feito passar um não cigano para trás. O gadjô é uma fonte para negociações, mas, assim que se termina uma dessas interações, o cigano volta ao seu 'território', ao seja, ao acampamento, à tenda ou algo parecido, pois, mesmo quando mora em casa, ela tende a imitar a tenda. Ás vezes chegam a tirar as portas, para que haja mais liberdade.

O cigano se considera livre, como vimos. Assim, "trabalho autônomo é tido mesmo como elemento da identidade cigana, pois dá a dimensão de liberdade em relação aos gadjé, mobilidade e flexibilidade, coerente dentro do contexto de suas relações ideológicas com a sociedade 
envolvente" (Fonseca, 1996: 14). Enfim, mesmo tendo sido perseguido durante muitos séculos, o cigano luta com unhas e dentes para manter a identidade romani ancestral, mesmo que tenha que abrir mão de alguns detalhes para não perder o todo. Os ciganos de Aparecida de Goiânia se tornaram evangélicos, com o que passaram a considerar muita coisa de suas tradições como não sendo algo de Deus ou algo parecido. No entanto, persistem não querendo trabalhar para os outros, exercendo o ofício de vendedores de colchas, toalhas e outras quinquilharias. Antes de tudo, porém, mantêm sua variedade de romani, o romanês, mesmo que desgastado pelo contato com o português. Tanto que entre eles procuram falar só em romanês, embora tendo que adotar diversos vocábulos da língua portuguesa envolvente.

Recebido: 20/09/2012

Aceito: $21 / 11 / 2012$

elzakm@terra.com.br

\section{Referências bibliográficas}

CHINA, J. B. O. Os ciganos do Brasil (subsídios históricos, ethnographicos e linguísticos). São Paulo: Imprensa Oficial do Estado, 1936.

COElHo, A. Os ciganos de Portugal - com um estudo sobre o Calão. Imprensa Nacional, Lisboa, 1892.

COUTO, H. H. do. Anticrioulo: manifestação linguística de resistência cultural. Brasília: Thesaurus, 2002.

Ecolinguística: estudo das relações entre língua e meio ambiente. Brasilia: Thesaurus, 2007.

FONSECA, M. de L. P. 1996. Espaço e cultura nos acampamentos ciganos de Uberlândia. Dissertação de Mestrado em Arquitetura, Universidade de Brasília.

HANCOCK, I. F. A handbook of Vlax Romani. Columbus: Slavica Publishers, 1995. 
MELO, F. J. D. de. Os ciganos de Mambaí: a sobrevivência de sua língua. Brasilia: Thesaurus, 2005.

MOONEN, F. Ciganos na Europa e no Brasil, MS. Brasília:Thesaurus,1997.

Cigano Calon na cidade de Sousa, Paraíba. In: MOTA, Ático V-B da. Ciganos - Antologia de ensaios. Brasília:Thesaurus, 2004.

MORAES FILHO, M. Os ciganos do Brasil e o cancioneiro dos ciganos. Ed. Itatiaia e Ed.da Universidade de São Paulo, 1981.

MOTA, A . V-B. da. Os ciganos: uma minoria discriminada. In: Revista Brasileira de Política Internacional. Rio de Janeiro, 1986.

WITTGENSTEIN, Ludwig. Tractatus logico-philosophicus. São Paulo: Cia. Editora Nacional \& Editora da USP, 1968. 